\title{
PENCEGAHAN DINI CACINGAN PADA ANAK USIA PRA SEKOLAH DENGAN PRAKTEK CUCI TANGAN PAKAI SABUN YANG BAIK DAN BENAR DI PAUD ANYELIR MEDAN
}

\author{
Minda Sari Lubis, S. Farm., M.Si., Apt. \\ Program Studi Farmasi, Fakultas Matematika dan Ilmu Pengetahuan Alam, \\ Universitas Muslim Nusantara Al Washliyah Medan \\ Email: mindimindi@ymail.com
}

\begin{abstract}
ABSTRAK
Pencegahan dini cacingan pada anak usia pra sekolah dengan praktek cuci tangan pakai sabun yang baik dan benar di paud anyelir medan telah dilaksanakan. Kegiatan ini bertujuan: untuk mendeskripsikan aktivitas pembelajaran mencuci tangan melalui metode demonstrasi, mendeskripsikan tingkat efektivitas metode demonstrasi dalam pembelajaran mencuci tangan pada Sekolah Paud Anyelir di Medan, guru diharapkan dapat memperbaiki dan meningkatkan kualitas proses dan hasil pembelajaran mencuci tangan dan membiasakan melaksanakan penelitian tindakan kelas. Anak-anak pra sekolah bagi anak-anak yang berumur 3-5 tahun agar dapat meningkatkan kemampuan mencuci tangan melalui metode demonstrasi, sekolah adalah salah satu pedoman untuk merencanakan program pembelajaran dan menjadi acuhan dalam melengkapi sarana dan prasarana pembelajaran. Pelaksanaan Pencegahan dini cacingan pada anak usia pra sekolah dengan praktek cuci tangan pakai sabun yang baik dan benar di paud anyelir medan telah dilaksanakan berjalan dengan baik, indicator keberhasilan kegiatan dapat dilihat dari kelompok mitra telah berhasil membuat pedoman pendidikan anak dan peranserta kelompok mitra dalam kegiatan yang dilaksanakan sangat aktif.
\end{abstract}

Kata Kunci: Penyuluhan dan Pelatihan, Pencegahan Dini Cacingan Pada Anak, Praktek Cuci Tangan

\begin{abstract}
Early prevention of intestinal worms in children of preschool age with the practice of hand washing with soap is good and right in the early childhood field carnation has been implemented. The aim of this activity: to describe the learning activity through a hand washing demonstration method, describe the level of effectiveness of the demonstration method in teaching hand washing at school early childhood Carnations in Medan, teachers are expected to improve and enhance the quality of the learning process and results of washing hands and getting used to carry out action research. Children pre-school for children aged 3-5 years in order to improve the ability to wash hands through the method of demonstration, the school is one of the guidelines to plan learning programs and be acuhan in completing the learning infrastructure. Implementation of Early prevention of worms in children of preschool age with the practice of hand washing with soap is good and right in the early childhood field carnation has been implemented going well.
\end{abstract}

Keywords: Counseling And Training, Early Prevention Of Intestinal Worms In Children, The Practice Of Hand Washing

\section{PENDAHULUAN}

Sering sekali kita lihat pada anakanak sekarang kurangnya menjaga kebersihan diri mereka sendiri jika tidak ada orang dewasa yang mengingatkan mereka untuk membersihkan tangan mereka setelah mereka melakukan suatu kegiatan yang membuat tangan mereka menjadi kotor. Kurangnya pengetahuan mereka tetang manfaat dari menjaga kebersihan tangan mereka agar terhindar dari kuman yang dapat menyebabkan berbagai penyakit yang salah satunya adalah cacingan dan juga kurangnya 
sosialisasi terhadap anak-anak usia pra sekolah tentang bagaimana cara membersihkan tangan yang baik dan benar Dalam Permendiknas Nomor 58 Tahun 2009 disebutkan bahwa tingkat pencapaian perkembangan motorik kasar anak usia 5-6 tahun diantaranya adalah melakukan kegiatan kebersihan diri, indikatornya antara lain mengurus dirinya sendiri tanpa bantuan missal mencuci dan melap tangan. Pada buku Pedoman Pembinaan Kesehatan Anak Didik Taman Kanak-Kanak (Depkes RI, 2008) disebutkan bahwa salah satu pelayanan kesehatan rutin anak TK adalah cuci tangan sebelum dan sesudah makan. Selain itu pada Pelaksanaann UKS (Usaha Kesehatan Sekolah) di TK, cuci tangan sebelum dan sesudah makan merupakan salah satu prinsip hidup sehat yang diajarkan melalui pola pembiasaan. Melaksanakan perilaku hidup bersih dan sehat dengan bentuk kegiatan membiasakan cuci tangan sebelum makan merupakan pembinaan kualitas jasmani, kesehatan dan gizi berbasis sumber gizi yang terdiversifikasi pada. Pembinaan Kesiswaan TK.

Secara spesifik mengajarkan mencuci tangan pada anak usia dini akan membawa banyak manfaat, antara lain yaitu

1. Melatih berkomitmen dan disiplin

Mencuci tangan menjadi pola kebiasaan hidup yang baik bagi anak sampai dewasa nanti. Anak akan belajar untuk memiliki komitmen dan dedikasi yang kuat, serta disiplin berlatih dan membiasakan diri mencuci tangan dengan benar

2. Kesehatan fisik.

Dengan melakukan dan membiasakan diri mencuci tangan dengan benar, anak terbiasa berpola perilaku hidup bersih dan meningkatkan kesehatannya.

Kurangnya pengetahuan yang didapatkan oleh anak pra sekolah tentang menjaga kebersihan dirinya sendiri dapat ditingkatkan dengan adanya pemberitahuan secara langsung kepada anak-anak pra sekolah tentang bagaimana menjaga kebersihan tangan agar terhindar dari cacingan ataupun penyakit lainnya yang disebabkan oleh kuman.

Anak-anak pra sekolah di Paud Anyelir Medan masih kurang untuk mendapat info dan bagaimana cara melakukan mencuci tangan yang baik dan benar agar tidak cacingan, terutama pada anak usia 3-5 tahun yang melakukan kegiatan atau bermain diluar sekolah dari pada diruangan sehingga lebih besar kemungkinan mereka untuk cacingan.

\section{METODE PELAKSANAAN}

Metode pelaksanaan kegiatan yang akan dilakukan adalah metode ceramah dan diskusi. Langkah kerja:

1. Pembuatan Poster dan Leaflet

Poster dan leaflet yang dibuat merupakan poster dan leaflet yang informatif, edukatif, dan atraktif, sehingga dapat menarik perhatian khalayak masyarakat yang berkunjung ke unit-unit pelayanan kesehatan tersebut.

2. Penyiapan bahan yang perlukan 
Adanya persiapan untuk bahan yaitu mempersiapakan sabun untuk mencuci tangan dan memastikan kelancaran dari air di sekolah Paud Anyelir di Medan tersebut.

3. Sosialisasi kepada guru terlebih dahulu

Kegiatan sosialisasi kepada guru ini tentang bagaimana mencuci tangan yang baik dan benar dilakukan agar saat sosialisasi pada anak-anak paud lebih efektif dan menarik untuk dilakukan pleh anak-anak Paud Anyelir di Medan tersebut.

4. Memberikan info kepada anakanak paud dan pemberian poster Dilakukan kegiatan ini kepada anak-anak paud agar mereka lebih memahami bagaimana mencuci tangan yang baik dan benar dan penyebab dari tidak menjaga kebersihan tangan yaitu terkena cacingan sebelum dilakukannya praktek langsung kepada anak-anak paud tersebut.

5. Melakukan cara mencuci tangan yang baik

Dapat dijelaskan atau dipraktekkan secara langsung bagaimana mencuci tangan yang baik dengan anak-anak Paud Anyelir di Medan agar anak-anak paud pra sekolah mengikutinya dengan baik.

\section{HASIL DAN PEMBAHASAN}

Pencegahan dini cacingan pada anak usia pra sekolah dengan praktek cuci tangan pakai sabun yang baik dan benar di paud anyelir medan
Dilakukan dengan metode pendekatan dan diskusi, kegiatan dilakukan dan diawali dengan peninjauan lokasi, diskusi dan pengurusan perijinan pada Paud Anyelir Medan. Sebelum dilakukan pelaksanaan kegiatan sebelumnya telah dilakukan diskusi dengan kepala Sekolah tentang teknik-teknik dilapangan meliputi tanggal kegiatan, lokasi dan bahanbahan yang dibutuhkan, sehingga pelaksanaan kegiatan dapat berjalan dengan baik.

\section{Model Pelaksanaan Kegiatan}

Model Pelaksanaan kegiatan yang dilakukan adalah dengan memberikan Materi tentang bagaimana cara mencuci tangan yang baik dan benar

\section{Proses Pelaksanaan Kegiatan}

Adapun rangkaian kegiatan tersebut dapat dilihat pada Tabel 1. 
Tabel 1. Kegiatan pencegahan dini cacingan pada anak usia pra sekolah dengan praktek cuci tangan pakai sabun yang baik dan benar.

\begin{tabular}{|c|c|}
\hline \multicolumn{2}{|c|}{ Pertemuan I } \\
\hline Kegiatan & Penyusunan Buku Panduan cuci tangan pakai sabun yang baik dan benar \\
\hline Luaran & Draft Buku Panduan cuci tangan pakai sabun yang baik dan benar \\
\hline \multicolumn{2}{|c|}{ Pertemuan II } \\
\hline Kegiatan & $\begin{array}{l}\text { Fiksasi Penyusunan Buku Panduan cuci tangan pakai sabun yang baik } \\
\text { dan benar }\end{array}$ \\
\hline Luaran & Buku Panduan cuci tangan pakai sabun yang baik dan benar \\
\hline \multicolumn{2}{|c|}{ Pertemuan III } \\
\hline Kegiatan & Penyusunan video Panduan cuci tangan pakai sabun yang baik dan benar \\
\hline Luaran & video Panduan cuci tangan pakai sabun yang baik dan benar \\
\hline \multicolumn{2}{|c|}{ Pertemuan IV } \\
\hline Kegiatan & $\begin{array}{l}\text { 1. Pengurusan perizinan pelaksanaan kegiatan pencegahan dini } \\
\text { cacingan pada anak usia pra sekolah dengan praktek cuci } \\
\text { tangan pakai sabun yang baik dan benar } \\
\text { 2. Penetapan jadwal kegiatan pelaksanaan pencegahan dini } \\
\text { cacingan pada anak usia pra sekolah dengan praktek cuci } \\
\text { tangan pakai sabun yang baik dan benar }\end{array}$ \\
\hline Luaran & $\begin{array}{l}\text { Adapun luaran yang dihasilkan, yaitu } \\
\text { 1. Izin Pelaksanaan } \\
\text { 2. Jadwal Kegiatan pencegahan dini cacingan pada anak usia pra } \\
\text { sekolah dengan praktek cuci tangan pakai sabun yang baik dan } \\
\text { benar }\end{array}$ \\
\hline \multicolumn{2}{|c|}{ Pertemuan V } \\
\hline Kegiatan & $\begin{array}{l}\text { 1. Pendidikan dan pelatihan Peningkatan kegiatan pencegahan } \\
\text { dini cacingan pada anak usia pra sekolah dengan praktek cuci } \\
\text { tangan pakai sabun yang baik dan benar di paud anyelir Medan } \\
\text { 2. Memberikan pendidikan dan pelatihan inovasi dalam membuat } \\
\text { program pendidikan anak }\end{array}$ \\
\hline Luaran & $\begin{array}{l}\text { Adapun luaran yang dihasilkan, yaitu } \\
\text { 1. Kreatifitas Orang tua Meningkat } \\
\text { 2. Panduan program pendidikan anak }\end{array}$ \\
\hline Tujuan & $\begin{array}{l}\text { Adapun tujuan yang diharapkan dari peserta kegiatan, yaitu: } \\
\text { 1. Kemampuan berfikir yang baik dalam kebersihan anak. } \\
\text { 2. Memahami manajemen mendidik anak dengan menggunakan } \\
\text { panduan program pendidikan anak yang telah dirancang. }\end{array}$ \\
\hline
\end{tabular}

kegiatan pencegahan dini cacingan pada anak usia pra sekolah dengan praktek cuci tangan pakai sabun yang baik dan benar di paud 
anyelir Medan berjalan dengan baik, indikator keberhasilan kegiatan dapat dilihat dari kelompok mitra telah berhasil membuat beberapa pedoman pendidikan anak sesuai dengan keadaan atau kondisi anak kelompok mitra masingmasing dan peran serta kelompok mitra dalam kegiatan yang dilaksanakan sangat aktif yang ditinjau dari tanya jawab yang dilakukan saat diskusi serta dalam penyusunan program pendidikan anak mereka.

\section{KESIMPULAN}

Dari Pelaksanaan tahapan kegiatan pencegahan dini cacingan pada anak usia pra sekolah dengan praktek cuci tangan pakai sabun yang baik dan benar di paud anyelir Medan berjalan baik dan sesuai dengan jadwal kegiatan.

1. Peserta memiliki pengetahuan dan kerampilan tentang bagaimana mencuci tangan menggunakan sabun dengan baik dan benar.

2. Produk buku saku Panduan cuci tangan pakai sabun yang baik dan benar yang dihasilkan masih sederhana sehingga sifatnya masih sementara dan belum dapat digunakan sebagai acuan yang mutlak maka perlu dilakukan pengembangan lebih lanjut.

3. Untuk keberlanjutan program perlu dilakukan pendampingan dan motivasi dalam meningkatkan kebersihan untuk kesehatan anak.

\section{SARAN}

Masih perlu untuk terus dilakukan pendampingan sehingga harapannya kelompok mitra dapat memiliki kemauan yang tinggi untuk meningkatkan kesadaran akan kebersihan tangan, sehingga terciptanya pencegahan dini cacingan pada anak dimasa yang akan datang.

\section{UCAPAN TERIMAKASIH}

Ucapan Terimakasih kami sampaikam kepada Rektor Universitas Muslim Nusantara Al Washliyah Medan atas dana Internal Perguruan Tinggi, ucapan terikasih juga kami sampiakan kepada LPPM UMN Al Washliyah yang telah memfasilitasi dan membantu dalam pelaksanaan kegiatan IbM ini.

\section{REFERENSI}

Aisyah, Nur. Dkk. Meningkatkan Kemampuan Mencuci Tangan Melalui Metode Demonstrasi Pada Kelompok B Di TK Unggulan Terpadu AL Kautsar. Fakultas Ilmu Pendidikan, Universitas Negeri Surabaya: Surabaya.

Christin, Payastri. Dkk. Pengaruh Bernyanyi Lagu Cuci Tangan Terhadap Pelaksanaan Teknik Mencuci Tangan Pada Anak Usia Prasekolah (5-6 Tahun) di Paud Kumara Loka. Program Studi ilmu Keperawatan Fakultas Kedokteran Universitas Udayana: Denpasar

Mustafa, Preliana. Dkk. 2013. Hubungan Antara Perilaku 
Tentang Pencegahan Penyakit

Kecacingan Dengan Infestasi

Cacing Pada Siswa SD di

Kelurahan Bengkol Kecamatan

Mapanget Kota. Bidang Minat

Kesling Fakultas Kesehatan

Masyarakat Universitas Sam

Ratulangi: Manado.

Purwandi, Retno. Dkk. 2013.

Hubungan Antara Perilaku

Mencuci Tangan Dengan Insiden

Diare Pada Anak Usia Sekolah

Di Kabupaten. Jurnal

Keperawatan, ISSN: 2086-3071:

Jember. 